\title{
A case of gastropericardial fistula of a gastric tube after esophagectomy: a case report and review
}

Takehito Kato ${ }^{1}$, Takahiro Mori ${ }^{1,3^{*}}$, Koki Niibori ${ }^{2}$

\begin{abstract}
A 65-year-old man who had received an esophagectomy 10 years earlier was admitted to our hospital for right chest pain. Preoperative examinations showed pneumopericardium, a retrosternal gastric tube, and an active gastric tube ulcer. We diagnosed gastropericardial fistula of the gastric tube ulcer. Emergency surgery included lavage and drainage of the pericardial cavity and plombage of the rectus abdominis muscle flap to the posterior space of the gastric tube. Total parental nutrition and/or enteric nutrition were provided. Due to minor leakage from the ulcer, the patient could start oral intake on the postoperative $49^{\text {th }}$ day, and was discharged from the hospital on the postoperative $86^{\text {th }}$ day after physical rehabilitation. He has been free from complications for more than 33 months after surgery. Here, we review the literature and discuss the etiology and treatment of choice for this rare yet lethal complication in the follow-up after esophagectomy.
\end{abstract}

\section{Background}

Recent advances in thoracic surgery and post-surgical management in intensive care units (ICUs) have improved the survival of esophageal cancer patients after esophagectomy; many patients often survive more than five years. However, gastric tubes that replace esophagi may erode, leading to gastric tube cancer or perforated gastric tube ulcer. Complications after gastric tube ulcer depend on the posterior-mediastinal, retrosternal or subcutaneal location of the gastric tube. Perforated ulcers of gastric tubes in the posteriormediastinal or retrosternal spaces, if they penetrate the neighboring trachea, thoracic aorta, or pericardium, are often lethal [1-4].

We report here a rare rescued case of pericarditis due to gastropericardial fistula of the gastric tube ulcer after esophagectomy, and review 29 cases.

\section{Case presentation}

A 65-year-old Japanese man was taken to National Hospital Organization Mito Medical Center by ambulance for severe colic right chest and back pain. He was lucid

\footnotetext{
* Correspondence: tamori@med.tohoku.ac.jp

1 Department of Surgery, National Hospital Organization Mito Medical Center, 280 Sakuranosato, Ibaraki-machi, Ibaraki 311-3193 Japan
}

and body temperature was $36.7^{\circ} \mathrm{C}$. His blood pressure was $127 / 97 \mathrm{mmHg}$, but atrial fibrillation (af), tachycardia, and ST-segment elevations in V5 and V6 were observed in the electrocardiogram (Figure 1A). Cardiomegaly was observed in the chest X-ray (Figure 1B). Severe inflammation was apparent, with a white blood cell (WBC) count of $9,100 / \mu \mathrm{l}$ and $C$-reactive protein (CRP) of $21.87 \mathrm{mg} / \mathrm{dl}$ (Table 1, left). He was hospitalized in the Department of Cardiology and conservatively treated with fluid replacement and anti-biotic chemotherapies (cefazolin). His condition worsened, with WBC and CRP increasing to $12,100 / \mu \mathrm{l}$ and $30.34 \mathrm{mg} / \mathrm{dl}$, respectively, with liver and renal dysfunction (Table 1, right). Oxygen inhalation was required for worsening respiratory dysfunction, and he entered multi organ failure (MOF). Four days after admission, computed tomography (CT) showed pneumopericardium and a neighboring gastric tube that replaced the esophagus after esophagectomy (Figure 2A, B). The patient had a history of esophagectomy followed by reconstruction with a gastric tube via the retrosternal route for esophageal cancer 10 years previously in other hospital. One image in the whole body CT (Figure 2B) suggested the presence of a gastropericardial fistula protruding from the gastric tube and splitting the metal staples. Upper GI endoscopy confirmed an active open ulcer that 


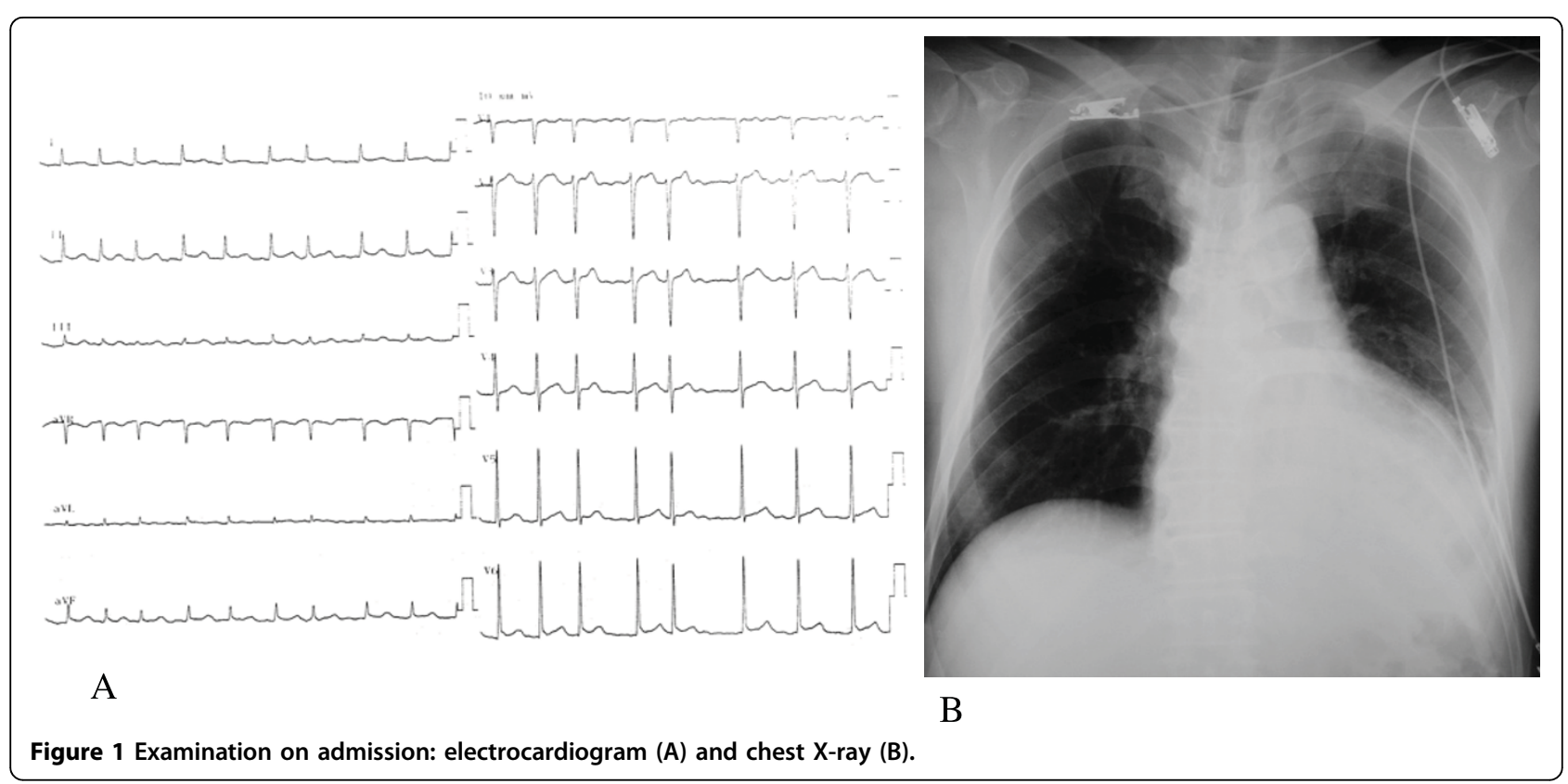

penetrated the pericardium within the gastric tube at 40 $\mathrm{cm}$ from the incisors (Figure $2 \mathrm{C}$ ).

We performed emergency surgery to rescue this patient from sepsis. First, we approached to gastric tube by upper median laparotomy, given the results of CT and upper GI endoscopy. The xiphoid process and lower tip of the sternum were removed, and many

Table 1 Laboratory data on admission and four days after admission (preoperative)

\begin{tabular}{|c|c|c|}
\hline & $\begin{array}{c}\text { On } \\
\text { admission }\end{array}$ & $\begin{array}{c}\text { Four days after admission } \\
\text { (preoperative) }\end{array}$ \\
\hline $\begin{array}{c}\text { White blood cell (cells/ } \\
\mu \mathrm{l})\end{array}$ & 9,100 & 12,100 \\
\hline $\begin{array}{l}\text { Red blood cell }(\times \\
\left.10^{4} \text { cells/ } / \mu l\right)\end{array}$ & 304 & 330 \\
\hline $\mathrm{Hb}(\mathrm{g} / \mathrm{dl})$ & 11.1 & 11.8 \\
\hline Hct (\%) & 31.2 & 33.9 \\
\hline Platelet $\left(\times 10^{4} / \mu \mathrm{l}\right)$ & 17.2 & 15.3 \\
\hline AST (IU/L) & 7 & 2,480 \\
\hline ALT (IU/L) & 6 & 903 \\
\hline ALP (IU/L) & 200 & 237 \\
\hline LDH (IU/L) & 147 & 2,000 \\
\hline Total bilirubin (mg/dl) & 0.5 & 0.6 \\
\hline BUN (mg/dl) & 25.5 & 64.9 \\
\hline Creatinine $(\mathrm{mg} / \mathrm{dl})$ & 0.7 & 1.6 \\
\hline UA (mg/dl) & 4.1 & 9.3 \\
\hline CK (IU/L) & 37 & 44 \\
\hline $\mathrm{Na}(\mathrm{mmol} / \mathrm{l})$ & 138 & 138 \\
\hline $\mathrm{K}(\mathrm{mmol} / \mathrm{l})$ & 4.0 & 4.3 \\
\hline $\mathrm{Cl}(\mathrm{mmol} / \mathrm{l})$ & 102 & 105 \\
\hline CRP (mg/dl) & 21.87 & 30.34 \\
\hline
\end{tabular}

adhesions were released via the right side of the minor curvature of the gastric tube to avoid injuring the right gastroepiploic artery (RGEA), which feeds the gastric tube pedicle and should be on the left side of the pedicle. We finally identified the gastropericardial fistula. A perforated ulcer of the gastric tube was detected near the bare metal staples that lined the minor curvature in the lower gastric tube, which were initially covered by seromuscular sutures as elsewhere on the gastric tube. The pericardium was opened only by releasing adhesions between the pericardium and gastric tube due to gastropericardial fistula. The pericardial abscess was saline-lavaged and a pericardial drainage tube was placed. A muscle flap was then prepared with the pedicled right rectus abdominis muscle to fill the space between gastric tube and pericardium, and wound was closed. We also drained gastric juice intermittently with a naso-gastric tube (NG tube). Post-operative CT showed the drainage tube in the pericardial space and a plombaged muscular flap between gastric tube and pericardium (Figure 3).

The pericardial abscess had already led to MOF, acute renal failure, liver dysfunction, as well as respiratory failure. Therefore, we postoperatively treated the patient in the ICU with mechanical ventilation, circulatory maintenance by catecholamines, and continuous hemodiafiltration (CHDF). For increased bilateral pleural effusion, we placed bilateral thoracic drainage tubes on the 4th postoperative day (POD). Blood oxygenation improved and he was released from mechanical ventilation on the 9th POD. On the 18th POD, gastrogram showed minor leakage from the gastric tube to the pericardium, but 


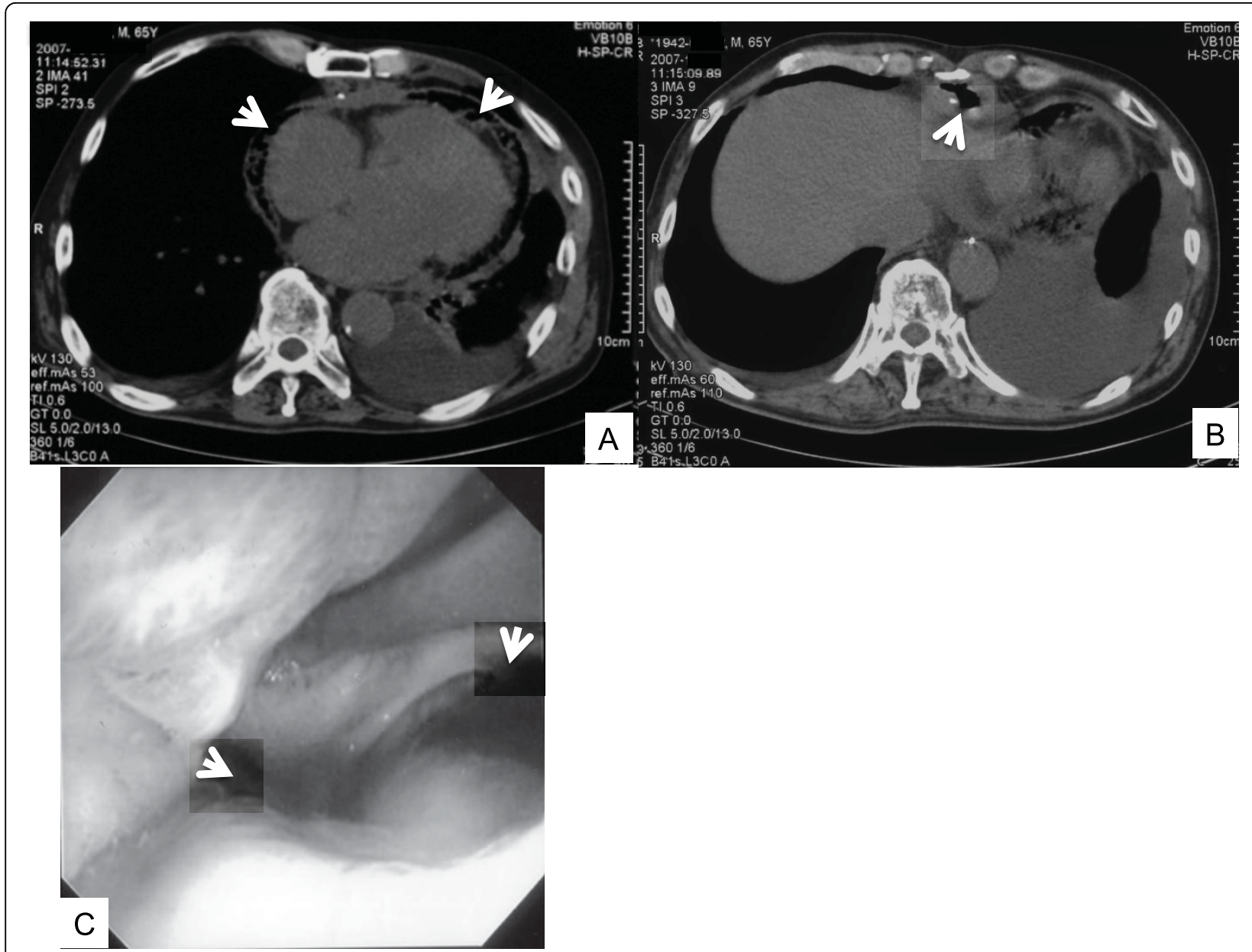

Figure 2 Pre-operative CT scans (A, B): arrows indicate pneumopericardium (A) or gastropericardial fistula (B); Preoperative upper GI endoscope shows the giant open ulcer within gastric tube, indicated by arrows (C).

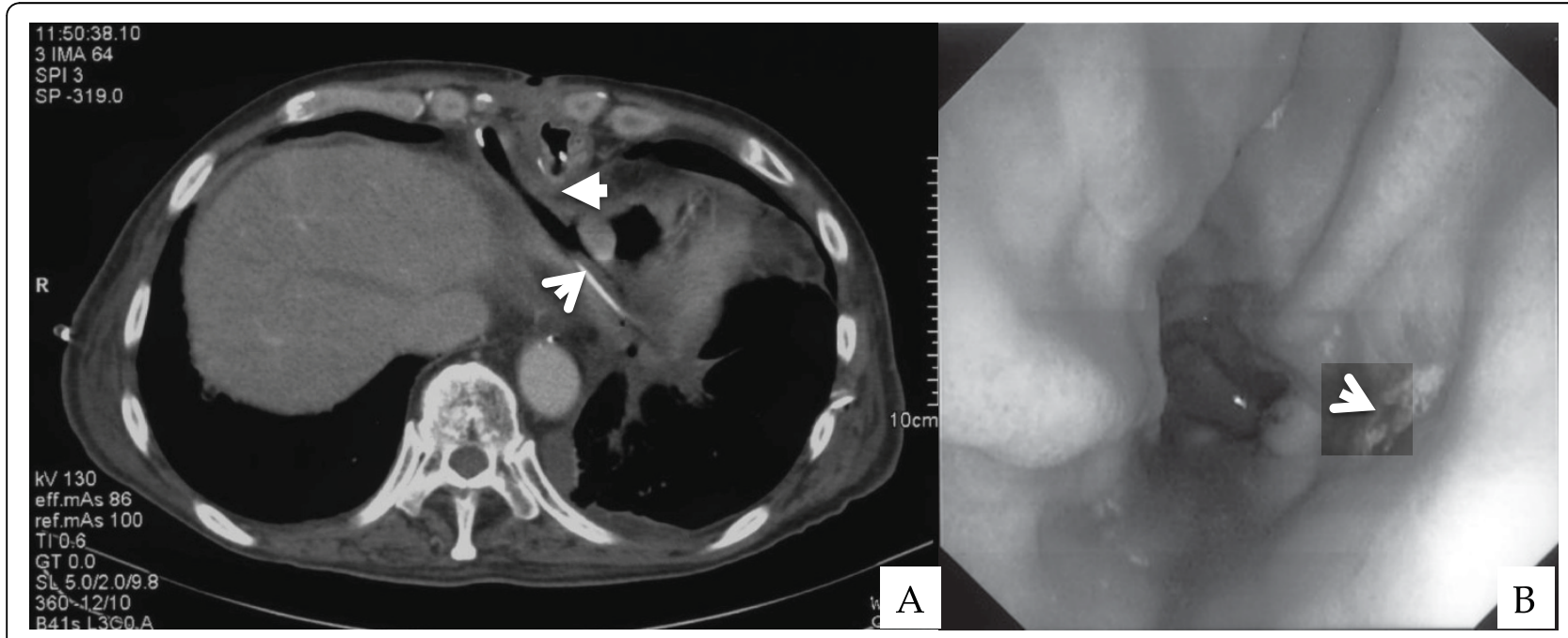

Figure 3 Post-operative CT shows pericardial drainage tube, indicated by an arrow, and muscular flap behind gastric tube, indicated by a triangular arrow (A); Postoperative upper Gl endoscopy shows the healing ulcer, indicated by an arrow (B). 
the drains were sufficient for pericardial drainage. He was treated with continuous pericardial drainage and nutrition support by enteric diet tube (ED tube) in the jejunum and/or by total parenteral nutrition via central venous catheter, because he sometimes experienced diarrhea with enteral tube feedings. On the 49th POD, leakage disappeared on the gastrogram, and the patient started oral intake by water drinking. On the 76th POD, gastroendoscopy showed a healing (H1) ulcer in the gastric tube (40 $\mathrm{cm}$ from the incisors) (Figure $3 \mathrm{~B}$ ). He was discharged from the hospital on the 86th POD, after physical rehabilitation. He has resumed daily life and is free from complications more than 33 months after surgery.

\section{Review of reported cases}

There are only two reports of a gastropericardial fistula of a gastric tube ulcer after esophagectomy $[1,5]$. The other 26 cases of pericardium-penetrating gastric tube ulcers have been reported in Japan, mostly Japanese conference proceedings or case reports in Japanese. All 29 cases, including the current case, are listed in Table 2; all cases were reconstructed via a retrosternal route, except two via a posterior mediastinum, one via intrathorax, and one unknown case. Postoperative durations vary from 2 months up to 12 years. Initial symptoms are usually chest pain or chest discomfort, with 12 patients (41\%) initially presenting at cardiovascular/internal medicine or general practitioners. The current case was presented to and primarily treated by cardiologists. Conservative therapy, percutaneous pericardial drainage, or surgical drainage was adopted for $10(37 \%)$, eight $(30 \%)$, and nine patients (33\%), respectively (Table 2 ). Thirteen patients were rescued, three in 10 by conservative therapies, two in six with trans-cutaneous drainage, including one that eventually needed additional surgical treatment, and eight in nine in surgical drainage; rescue ratios of $30 \%, 33 \%$, and $89 \%$, respectively. Prognosis in

Table 2 Reported cases of gastropericardial fistula of gastric tube ulcer since 1984, quoted and partially modified from a report by Shibutani et al

\begin{tabular}{|c|c|c|c|c|c|c|c|c|c|c|}
\hline \multirow[b]{2}{*}{ Case } & \multirow[b]{2}{*}{$\begin{array}{c}\text { Report } \\
\text { year }\end{array}$} & \multicolumn{2}{|c|}{ Patient } & \multirow{2}{*}{$\begin{array}{c}\text { Time } \\
\text { between } \\
\text { surgery } \\
\text { and } \\
\text { onset }\end{array}$} & \multirow[b]{2}{*}{$\begin{array}{l}\text { Reconstruction } \\
\text { route }\end{array}$} & \multirow[b]{2}{*}{$\begin{array}{l}\text { Primary } \\
\text { symptom }\end{array}$} & \multirow[b]{2}{*}{ Initial treatment } & \multirow[b]{2}{*}{ Modality for therapy } & \multirow[b]{2}{*}{ Outcome } & \multirow[b]{2}{*}{ Reference } \\
\hline & & Age & Sex & & & & & & & \\
\hline 1 & 1984 & 46 & Male & $\begin{array}{l}2 \text { years } 5 \\
\text { months }\end{array}$ & Retrosternal & Shock & Surgery & Conservative & Death & C. P.* [14] \\
\hline 2 & 1989 & 58 & Male & 3 years & Retrosternal & $\begin{array}{l}\text { Chest pain, } \\
\text { tachycardia }\end{array}$ & Internal medicine & Not described & Death & C. P. ${ }^{*}[15]$ \\
\hline 3 & 1991 & 67 & Male & 3 months & Retrosternal & $\begin{array}{l}\text { Precordial } \\
\text { pain }\end{array}$ & Surgery & Conservative & Death & ref. [1] \\
\hline 4 & 1993 & 66 & Male & 9 years & Retrosternal & Chest pain & Internal medicine & Conservative & Death & C. $P^{*}[16]$ \\
\hline 5 & 1993 & 57 & Female & 4 years & Intra-thoracic & $\begin{array}{l}\text { Retrosternal } \\
\text { pain }\end{array}$ & Internal medicine & Not described & Death & C. P. ${ }^{*}[17]$ \\
\hline 6 & 1996 & 66 & Male & $\begin{array}{l}1 \text { year } 9 \\
\text { months }\end{array}$ & $\begin{array}{l}\text { Posterior } \\
\text { mediastinal }\end{array}$ & Chest pain & Surgery & Conservative & Rescued & [18] \\
\hline 7 & 1997 & 74 & Male & 8 years & Retrosternal & $\begin{array}{l}\text { Precordial } \\
\text { pain }\end{array}$ & Surgery & $\begin{array}{l}\text { Surgical drainage (left } \\
\text { thoracotomy) }\end{array}$ & Rescued & [19] \\
\hline 8 & 1998 & 62 & Male & 2 months & Retrosternal & Shock & Surgery & Conservative & Death & [20] \\
\hline 9 & 1998 & N/A & & 2 years & Retrosternal & Shock & Surgery & $\begin{array}{l}\text { Surgical drainage (left } \\
\text { thoracotomy } \rightarrow \text { right } \\
\text { thoracotomy) }\end{array}$ & Death & C. P. ${ }^{*}[21]$ \\
\hline 10 & 1999 & 56 & Male & $\begin{array}{l}2 \text { years } 5 \\
\text { months }\end{array}$ & Retrosternal & $\begin{array}{l}\text { Precordial } \\
\text { pain }\end{array}$ & Internal medicine & $\begin{array}{l}\text { Surgical drainage, partial } \\
\text { resection of gastric tube }\end{array}$ & Rescued & C. P. ${ }^{*}[22]$ \\
\hline 11 & 1999 & 51 & Male & $\begin{array}{c}10 \\
\text { months }\end{array}$ & Retrosternal & $\begin{array}{l}\text { Chest pain, } \\
\text { back pain }\end{array}$ & Surgery & Percutaneous drainage & $\begin{array}{c}\text { Not } \\
\text { described }\end{array}$ & C. P. ${ }^{*}[23]$ \\
\hline 12 & 1999 & 68 & Male & $\begin{array}{l}1 \text { year } 4 \\
\text { months }\end{array}$ & Retrosternal & $\begin{array}{l}\text { Anorexia, } \\
\text { general } \\
\text { fatigue }\end{array}$ & Surgery & $\begin{array}{l}\text { Percutaneous drainage } \\
\text { surgical closure, partial } \\
\text { resection of pericardium }\end{array}$ & Rescued & C. P. ${ }^{*}[24]$ \\
\hline 13 & 1999 & 69 & Male & $\begin{array}{l}1 \text { year } 5 \\
\text { months }\end{array}$ & Retrosternal & Hematemesis & Surgery & Conservative & Rescued & C. P. $[25]$ \\
\hline 14 & 2000 & 54 & Male & 3 years & Retrosternal & $\begin{array}{l}\text { Chest pain, } \\
\text { dyspnea }\end{array}$ & $\begin{array}{l}\text { General } \\
\text { practitioner- } \\
\text { surgery }\end{array}$ & Percutaneous drainage & $\begin{array}{c}\text { Not } \\
\text { described }\end{array}$ & C. P. ${ }^{*}[26]$ \\
\hline 15 & 2000 & 67 & Male & 5 years & Retrosternal & $\begin{array}{l}\text { Precordial } \\
\text { pain }\end{array}$ & $\begin{array}{l}\text { General } \\
\text { practitioner }\end{array}$ & Percutaneous drainage & Death & {$[27]$} \\
\hline
\end{tabular}


Table 2 Reported cases of gastropericardial fistula of gastric tube ulcer since 1984, quoted and partially modified from a report by Shibutani et al (Continued)

\begin{tabular}{|c|c|c|c|c|c|c|c|c|c|c|}
\hline 16 & 2000 & 56 & Male & 7 months & Retrosternal & $\begin{array}{l}\text { Chest pain, } \\
\text { shock }\end{array}$ & Surgery & Conservative & Death & C. P. ${ }^{*}[28]$ \\
\hline 17 & 2003 & 53 & Male & $\begin{array}{l}4 \text { years } 2 \\
\text { months }\end{array}$ & Retrosternal & $\begin{array}{c}\text { Not } \\
\text { described }\end{array}$ & Not described & $\begin{array}{c}\text { Surgical drainage } \\
\text { (thoracotomy), partial } \\
\text { resection of gastric tube }\end{array}$ & Rescued & C. P. $[29]$ \\
\hline 18 & 2003 & 77 & Male & 4 years & Retrosternal & $\begin{array}{l}\text { General } \\
\text { fatigue }\end{array}$ & Surgery & Percutaneous drainage & Death & C. P. ${ }^{*}[30]$ \\
\hline 19 & 2003 & 65 & Male & 6 months & Retrosternal & Anorexia & Surgery & Conservative & Death & {$[31]$} \\
\hline 20 & 2004 & 66 & Male & $\begin{array}{c}\text { Not } \\
\text { described }\end{array}$ & Not described & Chest pain & Surgery & Drainage & Death & C. P. ${ }^{*}$ [32] \\
\hline 21 & 2006 & 68 & Male & $\begin{array}{l}2 \text { years } 6 \\
\text { months }\end{array}$ & Retrosternal & $\begin{array}{c}\text { Chest } \\
\text { discomfort, } \\
\text { odynophagia }\end{array}$ & Cardiology & $\begin{array}{l}\text { Drainage gastric tube } \\
\text { resection, pericardium } \\
\text { resection }\end{array}$ & Death & C. P. ${ }^{*}$ [33] \\
\hline 22 & 2006 & 64 & Female & 5 years & Retrosternal & Chest pain & $\begin{array}{l}\text { General } \\
\text { practitioner }\end{array}$ & $\begin{array}{c}\text { Surgical drainage (left } \\
\text { thoracotomy), TachoComb } \\
\text { sheets }\end{array}$ & Rescued & C. $P^{*}[34]$ \\
\hline 23 & 2007 & 72 & Male & 4 years & Retrosternal & $\begin{array}{c}\text { Chest } \\
\text { discomfort }\end{array}$ & Cardiology & Conservative & Death & {$[35]$} \\
\hline 24 & 2008 & 66 & Male & 5 years & Retrosternal & $\begin{array}{l}\text { General } \\
\text { fatigue }\end{array}$ & Surgery & Percutaneous drainage & Rescued & {$[36]$} \\
\hline 25 & 2008 & 60 & Male & 5 years & Retrosternal & $\begin{array}{l}\text { Omalgia, } \\
\text { fever }\end{array}$ & Surgery & $\begin{array}{c}\text { Surgical drainage (left } \\
\text { thoracotomy), muscle flap } \\
\text { plombage }\end{array}$ & Rescued & C. P.* [37] \\
\hline 26 & 2008 & 59 & Male & 12 years & $\begin{array}{l}\text { Posterior } \\
\text { mediastinal }\end{array}$ & $\begin{array}{l}\text { Precordial } \\
\text { pain }\end{array}$ & $\begin{array}{c}\text { General } \\
\text { practitionersurgery }\end{array}$ & Surgical drainage & Rescued & C. P. ${ }^{*}[38]$ \\
\hline 27 & 2009 & 46 & Female & $\begin{array}{l}1 \text { year } 1 \\
\text { months }\end{array}$ & Retrosternal & $\begin{array}{l}\text { Chest pain, } \\
\text { dyspnea }\end{array}$ & Surgery & Surgical drainage & Rescued & C. P.* [39] \\
\hline 28 & 2010 & 62 & Male & 8 years & Retrosternal & $\begin{array}{l}\text { Left omalgia, } \\
\text { melena }\end{array}$ & Internal medicine & Conservative & Rescued & {$[5]$} \\
\hline 29 & 2010 & 65 & Male & 10 years & Retrosternal & Chest pain & Cardiology & $\begin{array}{l}\text { Surgical drainage, muscle } \\
\text { flap plombage }\end{array}$ & Rescued & $\begin{array}{l}\text { Current } \\
\text { case }\end{array}$ \\
\hline
\end{tabular}

${ }^{*}$ C.P. $=$ Domestic conference proceedings reported in Japanese.

surgical drainage is much better than that in conservative therapies or in percutaneous drainage.

\section{Discussion}

The stomach is the organ most used for reconstructions after an esophagectomy for esophageal cancer patients; in Japan, a retrosternal route is preferred, where the gastric tube is pulled up [6]. Recent advances in surgical procedures as well as ICU care have improved the postoperative prognosis of esophageal cancer patients, but longer post-surgical periods can lead to problems with gastric tubes, such as bleeding, perforated ulcers, or gastric tube cancers. More than $13 \%$ of patients eventually have gastric tube ulcers [7], which can cause massive bleeding, perforation, or penetration through neighboring vital organs [1-4]. Gastropericardial fistula is highly lethal, with a high mortality of more than 50\% (Table 2). Almost all cases were reconstructed via the retrosternal route, as the gastric tube is close to the pericardium. The blood supply for the stomach is mostly dependent on the left gastric artery (LGA), so a gastric tube without the LGA reduces blood supply by $84 \%$ at distal sites or by $40 \%$ to $52 \%$ at middle or proximal sites, where blood supply is replaced by the RGEA [8]. Blood supply also declines more in the retrosternal than the posterior mediastinal route [9]. This decreased blood flow can cause the ulcer, even in the normal healing process [10]. This case showed a thinned, weakened gastric tube wall, with simple closure of a penetrated ulcer usually insufficient. Muscle flap plombage can help treat pericardial or mediastinal abscesses, as we used here with rectus abdominis muscle for a good outcome [11-13].

\section{Conclusions}

Esophageal cancer patients have prolonged survival after esophagectomy, but gastric tube ulcers can be life-threatening. We found that both surgical drainage and muscle flap plombage can be beneficial for treating ulcers. Gastropericardial fistula of a gastric tube ulcer should be part of the differential diagnosis in patients with an esophagectomy, especially via retrosternal route, that present with chest pain. Similarly, routine examination of the gastric tube by upper GI endoscopy could help avoid this high-mortality comorbidity. 


\section{Consent}

Written informed consent was obtained from the patient for publication of this case report and any accompanying images. A copy of the written consent is available for review by the Editor-in-Chief of this journal.

\section{Acknowledgements}

Authors are grateful to Drs. Kozaki, Koizumi, Sairenji, Yamaguchi and Ueki (Mito Medical Center, Ibaraki, Japan) for their suggestions and helpful advice for this patient's treatments.

\section{Author details}

'Department of Surgery, National Hospital Organization Mito Medical Center, 280 Sakuranosato, Ibaraki-machi, Ibaraki 311-3193 Japan. ${ }^{2}$ Department of Cardiovascular Surgery, National Hospital Organization Mito Medical Center, 280 Sakuranosato, Ibaraki-machi, Ibaraki 311-3193 Japan. ${ }^{3}$ Tohoku University Graduate School of Medicine, 1-1 Seiryo-cho, Aoba-ku, Sendai 980-8574 Japan.

\section{Authors' contributions}

TK was involved in the surgery and was a major contributor in writing the manuscript and preparing figures and tables. TM performed the emergency surgery and gave final approval of the version to be published. KN participated in the surgery team and performed pericardial lavage and drainage as a department chairman of Cardiovascular Surgery. All authors read and approved the final manuscript.

\section{Competing interests}

The authors declare that they have no competing interests.

Received: 10 May 2010 Accepted: 21 July 2010 Published: 21 July 2010

\section{References}

1. Shima I, Kakegawa T, Fujita $\mathrm{H}$, et al: Gastropericardial and gastrobrachiocephalic vein fistulae caused by penetrating ulcers in a gastric pedicle following esophageal cancer resection: a case report. Jpn J Surg 1991, 21:96-9.

2. Takemura M, Higashino M, Osugi H, Tokuhara T, Fujiwara K, Kinoshita H: Five cases of peptic ulcer of gastric tube after radical esophagectomy for esophageal carcinoma and analysis of Helicobacter pylori infection at gastric tube. Nippon Kyobu Geka Gakkai Zasshi 1997, 45:1992-7, (in Japanese).

3. Katsoulis IE, Veloudis G, Exarchos D, Yannopoulos P: Perforation of a gastric tube peptic ulcer into the thoracic aorta. Dis Esophagus 2001, $14: 76-8$.

4. Mochizuki Y, Akiyama S, Koike M, Kodera Y, Ito K, Nakao A: A peptic ulcer in a reconstructed gastric tube perforating the thoracic aorta after esophageal replacement. Jpn J Thorac Cardiovasc Surg 2003, 51:448-51.

5. Park S, Kim JH, Lee YC, Chung JB: Gastropericardial fistula as a complication in a refractory gastric ulcer after esophagogastrostomy with gastric pull-up. Yonsei Med J 2010, 51:270-2.

6. Ozawa S, Tachimori Y, Baba H, et al: Comprehensive registry of esophageal cancer in Japan, 2001. Esophagus 2009, 6:95-110.

7. Ide $H$, Eguchi $R$, Nakamura $T$, et al: Late management of patients after esophagectomy and reconstruction for esophageal cancer. Nippon Shokaki Geka Gakkai Zasshi (Jpn J Gastroenterol Surg) 1995, 28:2057-61, (in Japanese)

8. Itabashi T: A clinical study on the anastomotic leakage in surgery of esophageal cancer and blood flow of the reconstructed gastric tube. Akita J Med 1988, 15:467-83, (in Japanese).

9. Ishida K, Mori S, Watanabe M, Otsu T, Kikuchi M: A case report of peptic ulcer with gastric tube after resection of esophageal cancer. Shokaki Geka (Gastroenterol Surg) 1985, 8:1502-4, (in Japanese).

10. Kitai $T$, Inomoto $T$, Hanafusa $T$, et al: Oxygenation of the gastric tube after subtotal esophagectomy. Ther Res 2000, 21:1596-9, (in Japanese).

11. Kyo Y, Uchida N, Shibamura H, Ozawa M, Sueda T: A case of successful treatment for infectious false aneurysm after abdominal aortic aneurysm repair. Jpn J Vasc Surg 2006, 15:629-32, (in Japanese).
12. Noriyuki $T$, Kuroda $Y$, Shimomura M, et al: A case report of pyothorax with bronchopleural fistula treated by omentopexy, persadis dolis muscle flap, and intraoperative bronchoscopic bronchial embolization. Hiroshima lgaku 2006, 59:527-30, (in Japanese).

13. Tamura A, Takahara Y, Mogi K, Katsumata M: Mediastinitis following graft replacement of the ascending and total arch aorta in two cases. Jpn J Cardiovasc Surg 2006, 35:147-50.

14. Yasuda T: A case report (no English title). proceedings of 10th Hokkaido Shokudogan Danwakai: Hokkaido J Surg 1984, 29:246, (in Japanese).

15. Iwasawa T: A case report (no English title). proceedings of 377th KantoChiho Kai: Jpn J Rad 1989, 49:1574, (in Japanese).

16. Furukawa T, et al: A case report (no English title). proceedings of KantoChiho Kai: 222: J Jpn Soc Gastroenterol 1993, 90:2343, (in Japanese).

17. Matsushita T: A case report (no English title). proceedings of Kinki-Chiho Kai 56: Nippon Shokaki Geka Gakkai Zasshi (Jpn J Gastroenterol Surg) 1993, 90:968, (in Japanese).

18. Kawasaki M, Satou S, Takage Y, et al: A case of gastroepicardial fistula caused by perforating ulcer of the reconstructed gastric tube for esophageal carcinoma. Nippon Rinsho Geka Gakkai Zasshi 1996, 57:1365-70, (in Japanese).

19. Fukumoto A, Watanabe A, Yamada T, et al: A case of cardiac tamponade due to perforation of peptic ulcer in the gastric tube after surgery for esophageal cancer. Nippon Shokaki Geka Gakkai Zasshi 1997, 30:1756-60, (in Japanese).

20. Sueyoshi S, Fujita H, Yamada H: Peptic ulcer in gastric tube for esophageal replacement. Shokaki Naishikyo 1998, 10:43-9, (in Japanese).

21. Onohara Y: A case report (no English title). proceedings of 57th Yamaguchi Geka Gakkai: Nippon Rinsho Geka Gakkai Zasshi 1998, 59:2711, (in Japanese).

22. Hashida H, Mito Y, Takahashi Y, et al: A case report (no English title). proceedings of 54th Nihon Shoukaki Geka Gakkai. Nippon Shokaki Geka Gakkai Zasshi (Jpn J Gastroenterol Surg) 1999, 32:683, (in Japanese).

23. Handa K: A case report (no English title). proceedings of Nihon Hukubu Kyukyu Igakkai. J Abd Emerg Med 1999, 19:226, (in Japanese).

24. Sakano H, Kubota H, Uematsu T, et al: A case report (no English title). proceedings of 54th Nippon Shokaki Geka Gakkai. Nippon Shokaki Geka Gakkai Zasshi (Jpn J Gastroenterol Surg) 1999, 32:1866, (in Japanese).

25. Takamura K, Nishi M, Matsuoka Y, et al: A case report (no English title). proceedings of Nippon Shokaki Geka Gakkai. Nippon Shokaki Geka Gakkai Zasshi (Jpn J Gastroenterol Surg) 1999, 32:2500, (in Japanese).

26. Somei S, Hanyu N, Ishibashi Y, et al: A case report (no English title). proceedings of Nippon Rinsho Geka Gakkai Nippon Rinsho Geka Gakkai Zasshi 2000, 61:691, (in Japanese).

27. Miyazawa $H$, Kikuchi $Y$ : A case of penetration to the pericardium of ulcer of the reconstructed gastric tube four years after surgery for esophageal cancer. Nippon Rinsho Geka Gakkai Zasshi 2000, 61:2621-5, (in Japanese).

28. Hayashi T, Sekokuchi T, Hirose S, et al: A case report (no English title). proceedings of Nihon Hukubu Kyukyu lgakkai. J Abd Emerg Med 2000, 20:901, (in Japanese).

29. Hosoi N: A case report (no English title). proceedings of 58th Nippon Shokaki Geka Gakkai. Nippon Shokaki Geka Gakkai Zasshi (Jpn I Gastroenterol Surg) 2003, 36:980, (in Japanese).

30. lida M, Suzuki M: A case report (no English title). proceedings of 65th Nippon Rinsho Geka Gakkai. Nippon Rinsho Geka Gakkai Zasshi 2003, 64:897, (in Japanese).

31. Ide N, Ito S, Nakamura A, et al: A case of gastropericardial fistula caused by a perforated ulcer in the reconstructed gastric tube after operation for esophageal cancer. Geka 2003, 65:1351-4, (in Japanese).

32. Yasuda A: A case report (no English title). proceedings of 59th Nippon Shokaki Geka Gakkai. Nippon Shokaki Geka Gakkai Zasshi (Jpn I Gastroenterol Surg) 2004, 37:1154, (in Japanese).

33. Tamaki Y: A case report (no English title). proceedings of 34th Nihon Kyukyu lgakukai. Nihon Kyukyu Igakukai Zasshi 2006, 17:497, (in Japanese).

34. Koike M: A case report (no English title). proceedings of 59th Nihon Kyobu Geka Gakkai. Jpn J of Thor and Cardiovas Surgery 2006, 54:390, (in Japanese).

35. Nakauchi $Y$, Taniguchi M, Miyamura Y, et al: A case of penetration of the reconstructed gastric tube ulcer into the pericardium. J Jpn Soc Intensive Care Med 2007, 14:599-602, (in Japanese).

36. Shibutani M, Takeuchi K, Iwauchi T, et al: A case of a gastroepicardial fistula due to perforating ulcer of the reconstructed gastric tube after surgery for esophageal cancer. Nippon Rinsho Geka Gakkai Zasshi 2008, 69:47-51, (in Japanese). 
37. Mitsui T, Sugiura $H$, Takashima $N$, et al: A case report (no English title). proceedings of 63rd Nippon Shokaki Geka Gakkai. Nippon Shokaki Geka Gakkai Zasshi (Jpn J Gastroenterol Surg) 2008, 41:1494, (in Japanese).

38. Yamazaki $Y$, Yamamoto $S$, Aoki $\mathrm{H}$, et al: A case report (no English title). proceedings of 70th Nippon Rinsho Geka Gakkai. Nippon Rinsho Geka Gakkai Zasshi 2008, 69:468, (in Japanese).

39. Ryoutokuji T, Izumi Y, Miura A, et al: A case report (no English title). proceedings of 811th Geka Shudan Kai. Nippon Rinsho Geka Gakkai Zasshi 2009, 70:3762, (in Japanese).

doi:10.1186/1749-7922-5-20

Cite this article as: Kato et al.: A case of gastropericardial fistula of a gastric tube after esophagectomy: a case report and review. World Journal of Emergency Surgery 2010 5:20.

\section{Submit your next manuscript to BioMed Central} and take full advantage of:

- Convenient online submission

- Thorough peer review

- No space constraints or color figure charges

- Immediate publication on acceptance

- Inclusion in PubMed, CAS, Scopus and Google Scholar

- Research which is freely available for redistribution

Submit your manuscript at www.biomedcentral.com/submit
C Biomed Central 